\title{
THE RELATIONSHIP BETWEEN HEAD POSTURE AND LEVEL OF PHYSICAL ACTIVITY IN OFFICE WORKERS
}

\author{
Una Veseta \\ Riga Stradiņš University, Latvia \\ Irena Upeniece \\ Riga Stradiņš University, Latvia \\ Oskars Onzevs \\ Turiba University, Latvia \\ Inga Liepina \\ Latvian Academy of Sport Education, Latvia \\ Ineta Lice \\ Lice Ineta - physiotherapist practice, Latvia
}

\begin{abstract}
The purpose of this study was to discover the relationship between head and neck posture and level of physical activity for office workers. In our study, 66 subjects (women 2849 age old) who work in office longer than one year, sitting would total about 6 hours per 8 hour workday. Exclusion criteria were self-report of previous significant back injury; current neck or upper back pain; or referred pain into the upper extremity (i.e. cervical radiculopathy). Informed consent was obtained from all participants. Physical activity levels were evaluated using the International Physical Activity Questionnaire short form. The head posture and the craniovertebral angle was measured using photogrammetry, Protractor mobile application using iPhone 6s cell phone. The cervical Range of Motion was analyzed using the inclinometer and the Neck Disability Index as an instrument for self-rated disability. The collected data were analyzed using the methods of mathematical statistics. Pearson correlation was used to determine the relationship of level of physical activity with craniovertebral angle and Neck Disability Index. The results showed physical activity level has no correlations at all, a weak correlation to the craniovertebral angle. There is a correlation between all other head posture indicators.
\end{abstract}

Keywords: head posture, level of physical activity, office workers.

\section{Introduction}

Today, most employees spend their working day in a sitting position. It means - the office jobs are related to the static load. In the U.S., for example, more than $80 \%$ of all jobs are mostly sedentary, so full-time office employees face disorder, increased risk of cardiovascular and metabolic morbidity and mortality 
(Gremaud et al., 2018). Women are less physically active than men (Skidmore \& Carson, 2016). Sedentary lifestyles, stress at work and inactivity can lead to changes in the systems of support and movement. Musculoskeletal disorders are usually characterized by pain, mobility restrictions that reduce people's ability to work (James et al., 2018). One of the most frequent changes in systems of support and movement are localized in back and neck, followed by relevant pain (Tsakitzidis et al., 2009). Although the prevalence of musculoskeletal disorders is increasing with age, younger people are also affected, most often - during the peak of their economic activity (Impact of Musculoskeletal Disorders on Americans Opportunities for Action [IMDA-OA], 2016).

Physical activities are recommended as one of the non-pharmacological treatments (World Health Organization, 2019). Nevertheless, there are studies demonstrating that long-term sitting also affects health of people with sufficient physical activity (Vallance et al, 2018; Dunstan, Howard, Healy, \& Owen, 2012; Biswas et al., 2015). The key is that physical activity does not completely offset the negative effects of the unfavorable lifestyle centered on sitting (Ekelund et al., 2016; Koster et al., 2012).

Several studies have reported adverse health effects of the lack of physical activity on cardiovascular health (Evenson, Wen, \& Herring, 2016; Wilmot et al., 2012), back pain (Citko, Górski, Marcinowicz, \& Gorska, 2018), respiratory health (Jintae, Soojin, Youngju, Yeonsung, \& Hyeonnam, 2016) and endocrine system (Loprinzi \& Sng, 2016), etc. There is a lack of specific studies on the relationship of physical activity levels to head posture. The purpose of this study was to discover the relationship between head and neck posture and level of physical activity for office workers.

\section{Literature review}

The world is increasingly dominated by technologies that ease both professional and household life. Increasingly, less physical activities are needed to perform daily duties. Also travel and spare time are often accompanied by reduced physical activity. Evidence suggests that in the U.S. over the past 50 years the time of sedentary activities (during recreation and work) has increased from 26 to 38 hours a week, while in the U.K. between 30 and 42 hours a week, expressing troubling prospects for 2030 . This means that the number of 'sedentary occupations' has increased by $20 \%$, while it has decreased for 'physically active professions' (Ng \& Popkin, 2012).

Office employees spend the largest part of their working day in a sitting position and long-term sitting is associated with an increased health disorder risks (Mansfield et al., 2018). Looking at the possibility to increase the level of physical activity during out-off-office hours, it was concluded that there was a clear 
relationship between spare time during office hours and inactive behavior outside of working hours (Saidj et al., 2015).

The sedentary lifestyle is defined as long-term sitting in work, spare time and moving; these activities require energy spending of less than 1.5 metabolic equivalent of task (MET). Consequently, on average per week, the physical activity associated with the various 'performances' (professional work, mobility, homework, recreation and tourism) does not exceed $600 \mathrm{MET} / \mathrm{min} /$ per week (Leitzmann, Jockem, \& Schmid, 2018). The latest recommendations are that more health benefits would be if people reach 3,000 to 4,000 MET / min/ per week (World Confederation for Physical Therapy). 46\% of the population of the European Union did not carry out physical activities, unlike $56 \%$ of the population in Latvia (Sport and Physical Activity, 2017). Only 13\% of Latvia's population have physical activities at least half an hour a day, four to six times a week (Latvijas iedzīvotāju veselību ietekmējošo paradumu pētījums 2016).

From the sources of current literature, it can be concluded that men and women have different levels of physical activity, and these differences expose women to a variety of serious health problems and consequences (Skidmore \& Carson, 2016). Physical activities play an important role in strengthening women's health (Upeniece, Vinberga, Arnis, \& Erts, 2016).

A study by Diaz et al. (2017) found that regardless of the level of daily physical activities, if sitting becomes uninterrupted for more than 90 minutes, it increases the risk of mortality in the future. Therefore, the recommendation is to move every 30 minutes, since the time spent sitting is hazardous to health, regardless of the fact that physical activity is performed afterwards (Diaz et al., 2017).

Citko, Górski, \& Marcinowicz (2018) conducted a survey on medical personnel in the north-east of Poland on inactive lifestyles and non-specific lowerback pain. The findings were following - a sedentary lifestyle significantly increases the incidence of repeated back pain, while physical activity reduces the development of back pain. In the inactive lifestyle group it was founded that the presence of a metabolic disorder significantly increases the risk of non-specific back pain (Citko et al., 2018).

In many professions work takes long hours in static and inactive poses. This can lead to a continuous contraction of muscle in the neck and shoulders' muscles, which develops in most people the forward head posture (FHP) (Falla, 2004).

Consequently, FHP is a common disorder in society and is caused by longterm sitting at the desk (Kong, Kim, \& Shim, 2017). Maintaining static posture causes ligament damage around the spine and especially the neck. In addition, FHP is caused by muscle fatigue and reduced physical activity. A systematic review of prospective longitudinal studies allows conclude, that many people 
have FHP, but that doesn't mean a direct correlation with the neck pain (Damasceno et al., 2018).

\section{Methodology}

This is a pilot study for a cross-section correlation study, which aims to discover the relationship between head and neck posture and level of physical activity for office workers. The hypothesis was, that in office employees with a health-enhancing level of physical activity, the head position would be correct, but in office employees with insufficient physical activity would have FHP. Ethics Commission Meeting Protocol No. 239/42813.

Since 2013 a short version of the International Physical Activity Questionnaire (IPAQ) has been used in the private practice of physiotherapy (Veseta \& Līce, 2014), as it helps to determine the level of the customer's physical activity and, if necessary, to motivate customers' physical activities based on the results of the survey, as it is one of the of the physiotherapist's professional goals. The study analyzed client documents accumulated in outpatient physicality practice, which had an indication: "The client has agreed that his data is used for scientific research, subject to data protection rules and published only in aggregated form".

The study included 66 subjects (women - 28 to 49 years old) working in the office for more than one year, sitting down day-to-day for about 6 hours during 8 hours of work and normal (healthy weight), body mass index (BMI) $(\mathrm{kg} / \mathrm{m} 2)$ 18.5 to 25. The exclusion criteria were a self-assessment of the previous major spinal injury; regular neck or upper back pain; or pain in the upper part (i.e., neck radiculopathy).

The level of physical activity was assessed using the short form of the International Physical Activity Questionnaire (IPAQ-s). There are three levels of physical activities: insufficient physical activity, minimum physical activity required and health-enhancing physical activity. The short version of the IPAQ has been tested extensively and is used in many international studies (Hagströmer, Oja, \& Sjöström, 2006). Head position, craniovertebral angle (CVA) was measured using photogrammetry (a Protractor mobile app using an iPhone 6s mobile phone). Normal craniovertebral angle is 49.9 degrees. These measurements were carried out on the basis of a study, confirming the reliability of such measurements and underlining the need to use available measuring instruments in practice (Severinsson, Elisson, \& Bunketorp, 2012). The cervical Range of Motion was analyzed using the inclinometer that is approximate: flexion and extension $-45^{\circ}$, rotation $60^{\circ}-75^{\circ}$ and lateroflex $45^{\circ}-60^{\circ}$ in each direction. The neck disability index (NDI) was used as an instrument for self-assessed disability. 
Score: 0-4 - no disability; 5-14 - mild disability; 15-24 - moderate disability; 25-34 - severe disability; 35 or over - complete disability (IMDA-OA, 2016).

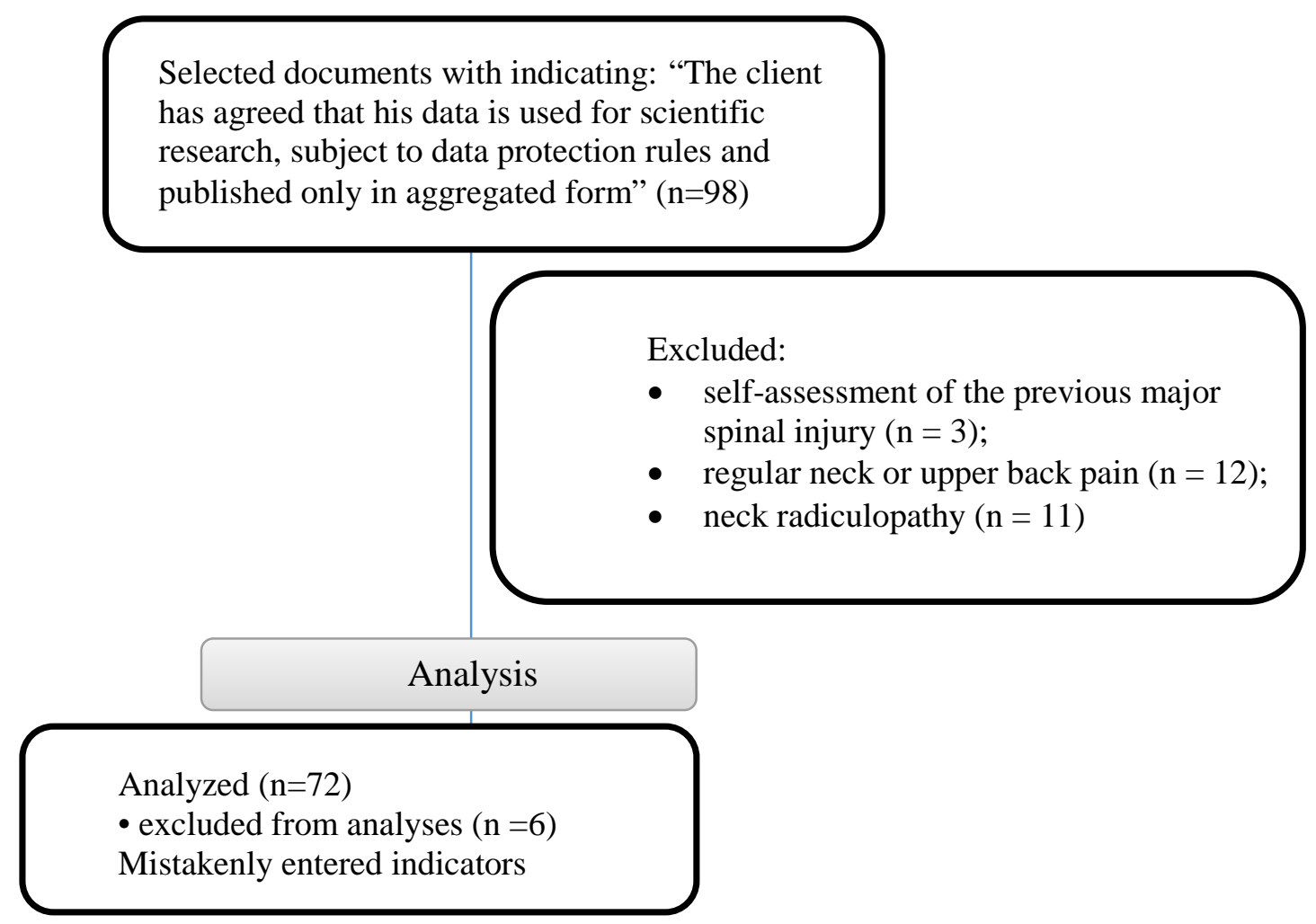

Figure 1 Study Flow Scheme

The collected data were analyzed using the methods of mathematical statistics. The statistical analysis used average and standartdeviation (SD). Independent t-test was used to identify differences between office employees with different levels of physical activity. Pearson's correlation was used to determine the relationship of the level of physical activity and CVA, IPAQ and NDI.

\section{Research results}

The study included 66 subjects (women - 28 to 49 years old) working in the office for more than one year, sitting down day-to-day for about 6 hours during 8 hours of work. The statistical analysis of baseline values is shown in Table 1. 
Table 1 The statistical analysis of baseline values

\begin{tabular}{|c|c|c|c|c|c|c|c|c|c|c|c|}
\hline & $\stackrel{\infty}{\infty}$ & $\sum_{m}$ & 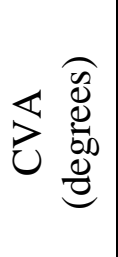 & 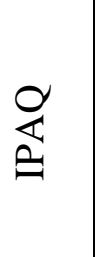 & $\overline{\mathrm{z}}$ & 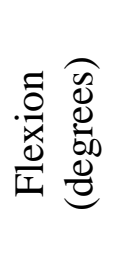 & 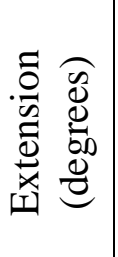 & : & 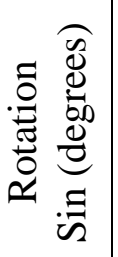 & 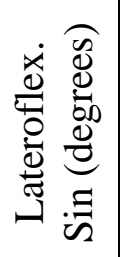 & 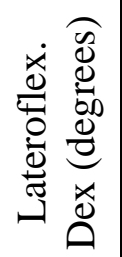 \\
\hline Mean & 38.85 & 23.98 & 42.42 & 2.03 & 5.30 & 38.17 & 34.89 & 45.3 & 45.15 & 40.95 & \\
\hline SD & 5.64 & 2.44 & 5.81 & 0.84 & 4.03 & 6.00 & 6.29 & 9.87 & 9.97 & 9.20 & 1 \\
\hline
\end{tabular}

By dividing the data obtained into three sub-groups according to the levels of physical activity: 1-minimum required physical activity, 2-almost sufficient physical activity and 3-health-enhancing physical activity, the relationship between these groups was established.

Table 2 Correlation between IPAQ and head posture data

\begin{tabular}{|l|r|r|r|r|r|l|l|l|l|}
\hline & CVA & IPAQ & NDI & Flexion & $\begin{array}{l}\text { Exten- } \\
\text { sion }\end{array}$ & $\begin{array}{l}\text { Rota- } \\
\text { tion } \\
\text { dex }\end{array}$ & $\begin{array}{l}\text { Rota- } \\
\text { tion sin }\end{array}$ & $\begin{array}{l}\text { Latero- } \\
\text { flexion } \\
\text { sin }\end{array}$ & $\begin{array}{l}\text { Latero- } \\
\text { flexion } \\
\text { dex }\end{array}$ \\
\hline CVA & 1 & & & & & & & & \\
\hline IPAQ & 0.41 & 1 & & & & & & & \\
\hline NDI & -0.86 & -0.37 & 1 & & & & & & \\
\hline Flexion & 0.77 & 0.32 & -0.73 & 1 & & & & & \\
\hline Extension & 0.82 & 0.38 & -0.78 & 0.83 & 1 & & & & \\
\hline Rotation dex & 0.76 & 0.25 & -0.82 & 0.74 & 0.70 & 1 & & & \\
\hline Latation sin & 0.77 & 0.33 & -0.82 & 0.74 & 0.74 & 0.93 & 1 & & \\
\hline Lateroflex. sin & 0.80 & 0.21 & -0.84 & 0.80 & 0.77 & 0.84 & 0.86 & 1 & \\
\hline
\end{tabular}

A zero hypothesis was tested during an analysis of dispersion. The hypothesis that the head position is affected by the level of physical activity can't be accepted. Table 2 shows that the level of physical activity does not correlate with the determinants of the head position. IPAQ has no correlations at all, a weak correlation to the CVA. There is a correlation between all other head posture indicators.

In Figure 2 shown mean values, SD, and trendline. An absolute trend of decreasing mean $\mathrm{R}^{2}=0.9$ indicates a linear relationship between IPAQ 1 mean value 7.3, SD 4.2, IPAQ 2 mean value 5, SD 3, IPAQ 3 mean value 3.8, SD 4.1. 


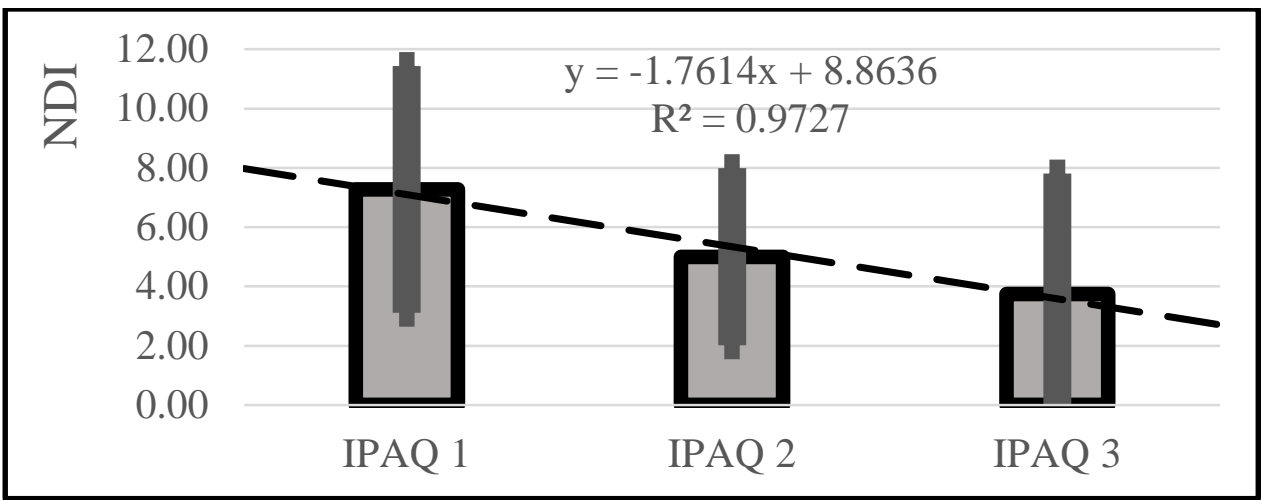

Figure 2 IPAQ level and NDI trendline

Figure 3. The differential function of the normal distribution shows the increased probability of NDI for lower levels of physical activity. The results of this study: IPAQ 1 mean value for NDI is mild disability, IPAQ 2 - 'borderline', and IPAQ 3 with NDI results in the mean range - no disability.

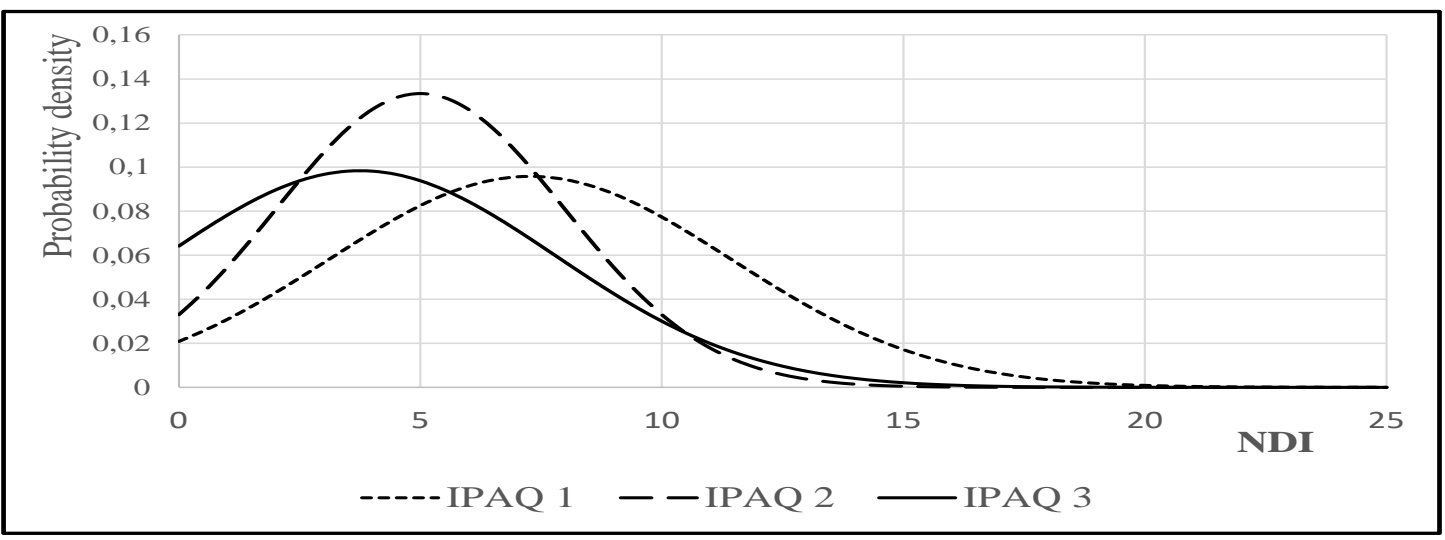

Figure 3 Differential function of the normal distribution (IPAQ and NDI)

\section{Conclusions}

This is a pilot study for a cross-section correlation study, which aims to discover the relationship between head and neck posture and level of physical activity for office workers. The hypothesis was that in office employees with a health-enhancing level of physical activity, the head position would be correct, but in office employees with insufficient physical activity would have FHP.

Following the results of the study it can be concluded, that the CVA for all subjects was reduced, did not correspond to normative indicators, i.e., presented the evidence of the FHP. The proportion (FHP) appears to be lower in cases of health-enhancing physical activity. The more physical activity, the smaller is 
proportion. The question is how this is achieved and why does it not affect equally?

By using dispersion analysis of the study results, a zero hypothesis was tested and concluded, that a hypothesis - head posture is affected by the level of physical activity - can't be accepted. The level of physical activity was shown to have no correlation with head posture determinants, a weak correlation with a CVA, but there is a correlation between all other head posture determinants.

The results of this study may be explained by pre-existing studies which have shown that in long-term sitting has a negative health impact also on people with sufficient physical activity (Vallance et al., 2018; Dunstan et al., 2012; Biswas et al., 2015). The key is that physical activity does not completely offset the negative effects of the unfavourable lifestyle centred on sitting (Ekelund et al., 2016; Koster et al., 2012).

Although the need for physical activity is constantly being reminded, in everyday life becomes less and less physically active. A large part of the day is spent at work, in addition to that - the number of 'sedentary occupations' has increased by $20 \%$, to compared to 'physically active professions" (Ng \& Popkin, 2012). Members of this study spend most of the day in a sitting position, like a study conducted by Mansfield et al. in 2018, which concludes that office employees spend most of their working day in a sitting position, and long-term sitting is associated with increased health disorder risks (Mansfield et al., 2018).

Researchers Damasceno et al., 2018 systematically reviewed prospective longitudinal studies and found that it was possible for many to find a FHP, but that doesn't mean a relationship to neck pain. Nor did the results of this study show a correlation between the CVA and NDI, but indicated the deviations of the CVA from the normal in all cases that suggests the importance of the problem. Perhaps this is also due to phone usage habits, which have also been studied and proven in many studies (Kong et al., 2017; Damasceno et al., 2018; Gustafssona, Thoméea, Grimby-Ekmana, \& Hagberga, 2017).

In the future a cross-sectional study on the CVA would be needed because, regardless of the daily level of physical activity and the absence of complaints, the angle determinants the, was detected outside the norm, which could lead to health problems in the future. Further studies and recommendations are essential to prevent changes in CVA.

\section{References}

Biswas, A., Oh, P.I., Faulkner, G.E., Bajaj, R.R., Silver, M.A., Mitchell, M.S., \& Alter, D.A. (2015). Sedentary time and its association with risk for disease incidence, mortality, and hospitalization in adults: a systematic review and meta-analysis. Annals of internal medicine, 162(2), 123-132. DOI: 10.7326/M14-1651. 
Citko, A., Górski, S., Marcinowicz, L., \& Gorska, A. (2018). Sedentary Lifestyle and Nonspecific Low Back Pain in Medical Personnel in North-East Poland. BioMed Research International. DOI: 10.1155/2018/1965807

Damasceno, G.M., Ferreira, A.S., Nogueira, L.A.C., Reis, F.J.J., Andrade, I.C.S., Meziat-Filho, N. (2018). Text neck and neck pain in 18-21-year-old young adults. European Spine Journal, 27(6), 1249-1254. DOI: 10.1007/s00586-017-5444-5.

Diaz, K.M., Howard, V.J., Hutto, B., Colabianchi, N., Vena, J.E., Safford, M.M., Blair, S.N., \& Hooker, S.P. (2017). Patterns of sedentary behavior and mortality in U.S. middle-aged and older adults: A national cohort study. Annals of internal medicine, 167(7), 465-475. DOI: $10.7326 / \mathrm{M} 17-0212$.

Dunstan, D.W., Howard, B., Healy, G.N., \& Owen, N. (2012). Too much sitting-a health hazard. Diabetes Research and Clinical Practice, 97(3), 368-76. DOI: 10.1016/j.diabres.2012.05.020

Ekelund, U., Steene-Johannessen, J., Brown, W.J., Fagerland, M.W., Owen, N., Powell, K.E., Bauman, A., \& Lee, I.M. (2016). Does physical activity attenuate, or even eliminate, the detrimental association of sitting time with mortality? A harmonised meta-analysis of data from more than 1 million men and women. The Lancet, 388(10051), 1302-10. DOI.org/10.1016/S0140-6736(16)30370-1

Evenson, K.R., Wen, F., \& Herring, A.H. (2016). Associations of Accelerometry-Assessed and Self-Reported Physical Activity and Sedentary Behavior With All-Cause and Cardiovascular Mortality Among US Adults. American Journal of Epidemiology, 184(9), 621-32. DOI: 10.1093/aje/kww070

Falla, D. (2004). Unravelling the complexity of muscle impairment in chronic neck pain. Manual Therapy, 9(3), 125-33. DOI: 10.1016/j.math.2004.05.003

Gremaud, A.L., Carr, L.J., Simmering, J.E., Evans, N.J., Cremer, J.F., Segre, A.M., Polgreen, L.A., \& Polgreen, P.M. (2018). Gamifying Accelerometer Use Increases Physical Activity Levels of Sedentary Office Workers. Journal of the American Heart Association, 7(13), e007735. DOI: 10.1161/JAHA.117.007735

Gustafssona, E., Thoméea, S., Grimby-Ekmana, A., \& Hagberga, M. (2017). Texting on mobile phone and musculoskeletal symptoms. A 5 years cohort study. Applied Ergonomics, 58, 208-214. DOI: 10.1016/j.apergo.2016.06.012.

Hagströmer, M., Oja, P., \& Sjöström, M. (2006). The International Physical Activity Questionnaire (IPAQ): a study of concurrent and construct validity. Public Health Nutrition, 9(6), 755-62. DOI: 10.1079/phn2005898

Impact of Musculoskeletal Disorders on Americans - Opportunities for Action. (2016). Bone and Joint Initiative USA [Data file]. Retrieved from https://www.boneandjointburden. org/docs/BMUSExecutiveSummary2016.pdf

James, S.L., Abate, D., Abate, K.H., Abay, S.M., Abbafati, C., Abbasi, N., ... \& Abdollahpour, I. (2018). Global, regional, and national incidence, prevalence, and years lived with disability for 354 diseases and injuries for 195 countries and territories, 1990-2017: a systematic analysis for the Global Burden of Disease Study 2017. The Lancet, 392(10159), 1789-1858. DOI: 10.1016/S0140-6736(18)32279-7.

Jintae, H., Soojin, P., Youngju, K., Yeonsung, C., \& Hyeonnam, L. (2016). Effects of forward head posture on forced vital capacity and respiratory muscles activity. Journal of Physical Therapy Science, 28(1), 128-131. DOI: 10.1589/jpts.28.128

Kong, Y.S., Kim, Y.M., \& Shim, J.M. (2017). The effect of modified cervical exercise on smartphone users with forward head posture. Journal of Physical Therapy Science, 29(2), 328-331. DOI: 10.1589/jpts.29.328 
Koster, A., Caserotti, P., Patel, K.V., Matthews, C.E., Berrigan, D., Van Domelen, D.R., Brychta, R.J., Chen, K.Y., \& Harris, T.B. (2012). Association of sedentary time with mortality independent of moderate to vigorous physical activity. Plos One, 7(6), e37696. DOI: 10.1371/journal.pone.0037696.

Leitzmann, M.F., Jockem, C., \& Schmid, D. (2018). Sedentary Behaviour Epidemiology. Springer Series on Epidemiology and Public Health. DOI 10.1007/978-3-319-61552-3.

Loprinzi, P.D., \& Sng, E. (2016). The effects of objectively measured sedentary behavior on all-cause mortality in a national sample of adults with diabetes. Preventive Medicine, 86, 55-57. DOI: 10.1016/j.ypmed.2016.01.023

Mansfield, L., Hall, J., Smith, L., Rasch, M., Reeves, E., Dewitt, S., \& Gardner, B. (2018). “Could you sit down please?” A qualitative analysis of employees' experiences of standing in normally-seated workplace meetings. Plos One, 13(6), e0198483. DOI: 10.1371/journal.pone.0198483

Ng, S.W., \& Popkin, B.M. (2012). Time Use and Physical Activity: A Shift Away from Movement across the Globe. Obesity Reviews, 13(8), 659-680. DOI: 10.1111/j.1467789X.2011.00982.x

Saidj, M., Menai, M., Charreire, H., Weber, C., Enaux, C., Aadahl, M., Kesse-Guyot, E., Hercberg, S., Simon, C., \& Oppert, J.M. (2015). Descriptive study of sedentary behaviours in 35,444 French working adults: cross-sectional findings from the ACTICités study. BMC Public Health, 15, 379. DOI: 10.1186/s12889-015-1711-8

Severinsson, Y., Elisson, L., \& Bunketorp, O. (2012). Reliability of Measuring the Cervical Sagittal Translation Mobility with a SimpleMethod in a Clinical Setting. Rehabilitation Research and Practice. DOI:10.1155/2012/629104

Skidmore, E.E., \& Carson, S.S. (2016). Psychosocial Variables Related to Why Women are Less Active than Men and Related Health Implications. Clinical medicine insights. Women's health, 4(9) (Suppl 1), 47-56. DOI: 10.4137/CMWH.S34668

Slimību profilakses un kontroles centrs. (2016). Latvijas iedzīvotāju veselību ietekmējošo paradumu pētījums [Data file]. Pieejams https://www.spkc.gov.lv/upload/ Petijumi\%20un\%20zinojumi/FINBALT/finbalt_2016_2.pdf

Sport and Physical Activity (2017). Special Eurobarometer Nr. 472. [Data file]. Retrieved from file:///C:/Users/Home/Downloads/ebs_472_fact_lv_en.pdf

Tsakitzidis, G., Remmen, R., Peremans, L., Van Royen, P., Duchesnes, C., Paulus, D., \& Eyssen, M. (2009). Non-specific neck pain: diagnosis and treatment. Good Clinical Practice (GCP). Brussels: Belgian Health Care Knowledge Centre (KCE). KCE Reports 119C. D/2009/10.273/56

Upeniece, I., Vinberga, I., Arnis, V., \& Erts, R. (2016). Women's Motivation to Engage with the Nordic Walking. Society. Integration. Education. Proceedings of the International Scientific Conference, VOL. III, 581-591. DOI: 10.17770/sie2016vol3.1474

Vallance, J.K., Gardiner, P.A., Lynch, B.M., D’Silva, A., Boyle, T., Taylor L.M., Johnson, S.T., Buman, M.P., \& Owen, N. (2018). Evaluating the Evidence on Sitting, Smoking, and Health: Is Sitting Really the New Smoking? American Journal of Public Health. 108(11), 1478-1482. DOI: 10.2105/AJPH.2018.304649

Veseta, U., \& Līce, I. (2014). Fizisko aktivitāšu līmenis un stāja 40-55 gadus vecām sievietēm. R̄̄gas Stradiña universitāte Zinātniskā conference, 10-11.

Wilmot, E.G., Edwardson, C.L., Achana, F.A., Davies, M.J., Gorely, T., Gray, L.J., Khunti, K., Yates T., \& Biddle, S.J.H. (2012). Sedentary time in adults and the association with diabetes, cardiovascular disease and death: systematic review and meta-analysis. Diabetologia, 55(11), 2895-905. DOI: 10.1007/s00125-012-2677-z. 
SOCIETY. INTEGRATION. EDUCATION

Proceedings of the International Scientific Conference. Volume VI, May $22^{\text {th }}-23^{\text {th }}, 2020.456-466$

World Confederation for Physical Therapy. How to measure physical activity [Data file]. Retrieved from https:/www.wcpt.org/sites/wcpt.org/files/files/wptday/17/Infographics/ MeasuringPhysicalActivity_infographic_A3_FINAL.pdf

World Health Organization. (2019). Musculoskeletal conditions [Data file]. Retrieved from https://www.who.int/news-room/fact-sheets/detail/musculoskeletal-conditions 